\title{
Structure, Strategy and Organizational Design in Albanian Context
}

\author{
MA. Ludmilla Shkurti PhD Cand. \\ Lecturer, SHLJU "Wisdom University”, Albania \\ ludmilla.shkurti@gmail.com
}

\section{Abstract}

This research paper will try to understand and explain how much and how is understood the nature, the importance and factors that affect the business organizational structure and design in Albanian Organizations, compared with theoretical factors researched from the literature. How a business does structure in our country, knowing how important are the theoretical factors in business organization performance and therefore how much and how the principles of organizational design are applied in Albanian Organizations. Why structure, strategy and organizational design? Organizational design and organizational restructuring remains one of the most important issues that management of organizations, in the global era and information technology, must deal with, for the fact that businesses today face some unprecedented challenges: increased competition, globalization, growing of social responsibility, technological changes, changes in taste and consumer's exigency, new strategic thinking, etc. Referring the literature and contemporary researchers, a constant topic during these recent years has been the one of how globalization and economic crisis have obliged the organizations to review their strategies and to change the way they operate, trying often therefore to structure for surviving and achieving success. These challenges should be carefully managed in order to build and hold a high performance organization, to deal with tough competition and endless problem that this era we live does bear. It is also important to understand correctly that organizational structure and design, by dictating roles connection in an organization and consequently how people function, may often be the main cause of the problems, but also one more reason of success. The way that organizations structure or the specific model of business, may constitute their competitive advantage, or special strategic skills, so it can make a business organization unique and competitive in the market. For many researchers the prevailing conclusion is that the organizations either neglect the importance of organizational design, or they just do not know what to do about it and therefore they evolve in an indirectly, spontaneous or intuitive way. From what the paper identifies, most of organizational structuring in Albania are made in a hasty way, without seeing or paying attention to full frame or circumstances. This may result in some partial and fragmentary initiatives instead of aiming in organizational designing and general structuring. This is not surprising as the subject is complex, often poorly explained and not rightly understood even though the academics and the consulters have made a great work to address the organizational design topic. However the paper shows that entrepreneurs and managers still lack a practical and systematic framework in order to guide their choices of organizational structure. To find a practical approach for the organizational design, can be difficult, even though some business schools have tried to simplify the things. The study will try to achieve this task, through careful research, in order to diagnose the organizational design process and restructuring situation in Albania, highlighting the effect of the current challenges which have an impact on this difficult process, mainly based on a survey of 200 organizational businesses in Albania.

Keywords: organizational design, organizational structure, strategy.

\section{Introduction}

This paper is part of a broader study, which relates to the discovery and then the analysis of the main factors of which are driven Albanian organizations during the organizational design process.

Consequently, the paper, this time will focus only on the analysis of the factors of context, aiming discovering the main factor, and further trying to discover if this factor in Albanian organizations is the strategy or not.

To indentify the main factors of which are theoretically driven organizations in organizational design process, the analysis is based on the literature review of some known researchers of the organizations domain as Burton and Obel (2004), Daft and Armstrong (2012), Burton, Eriksen, Håkonsson and Snow (2006),etc.

Although it is almost impossible to define all the possible factors that directly affect modern business practice indirectly the various trends in organizational and work level, it is necessary to mention those most important. The literature review identifies some key context factors that condition organizational design which are: Size, organizational technology, environment, goals \& strategy, culture. 


\section{The methodology}

The methodology consists of a combination of primary data with the secondary ones. The data from studies made by the Vlora District institutions such as Municipality, Prefecture, Chamber of Commerce and Industry, etc. is used.Private firms in Albanian cities such as Vlore, Fier, Lushnje, Saranda, Durres and Tirana are used to study the structure model. A questionnaire was drawn up to complete the findings and comparison. The questionnaire was designed to be addressed to the general managers of private firms, those of functions, or of the line ones, as well as to some experts. Questionnaires are standardized and uniform for all subjects included in the study. Questionnaires were distributed to 300 firms during the second half of 2011 and during 2012, 2013. Distribution of the questionnaire was made by personally interviewing individuals in each firm or via e-mail. The questionnaires took into consideration variables such as firm size, the year of their creation, knowledge about the structure and the organization's overall strategy, linking strategy organization for structuring future challenges.

A Factor analysis (principal factor) was used to give answer to the research question about the main factor that has an impact on the choice of organizational structure.

Research Question: Is the strategy the main factor that leads the choice of organizational design or an organizational structure?

The hypothesis $\mathrm{HO}$ :

The strategy is the main factor or the main dimension of context, which affects decision-making of business organizations in Albania for selecting and changing their organizational structure.

Hypothesis $\mathrm{H} 1$ :

The main factor influencing the decision-making of business organizations in Albania for selecting and changing the structure is not the strategy, but other factors dictated by the challenges currently faced by business organizations in Albania.

\section{FINDINGS AND DISCUSSION}

\subsection{Descriptive analyses}

The statistical data: 200 (returned) questionnaires (from 300 distributed) have been analyzed, with a distribution of business activity as follows:

Fig.1. Businesses by the Section of Economic Activity.

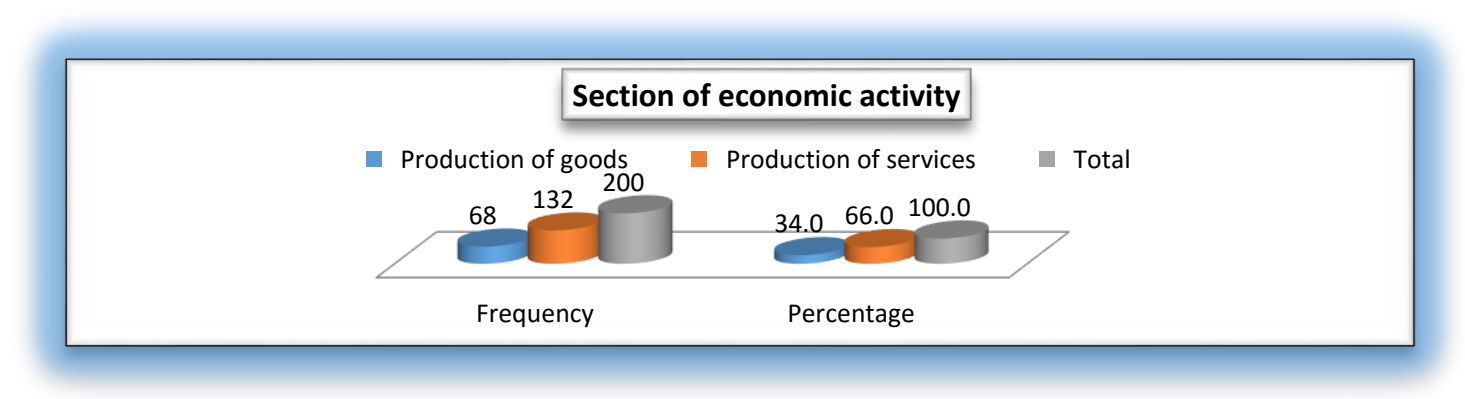

Source: Authors' research.

Question no 14: How much is based the establishing organizational structure (labour division) to;

- $\quad$ the financial ability 
- $\quad$ the other firms experiences (imitation)

- $\quad$ the spontaneous need shifted to experience/routine

- $\quad$ the casualty

According to the respondents' opinion, the main factor and /or other ones which have more impact on the Albanian organizational business structuring process and design are as follow:

Question no 14 : Respondents' Perception about Organizational Structure Factors

\begin{tabular}{|l|l|l|}
\hline Alternatives & Frequency & Percent \\
\hline 1Financial ability & 72 & 36.0 \\
\hline 2 Casualty & 25 & 12.5 \\
\hline 3 Imitation & 65 & 32.5 \\
\hline 4 Shift of the spontaneous need to exp. / routine & 30 & 15.0 \\
\hline 5 No response & 8 & 4.0 \\
\hline
\end{tabular}

Tab. 1. Respondents' Perception about Organizational Structure Factors

Source: Authors' research.

To the Question no 23: How much do you know about business organizational structure?

The answer "I have average knowledge "is given of the 38\% respondents only. (See the table no 2).

\begin{tabular}{|l|l|l|l|}
\hline $\mathbf{N r}$ & Alternatives & Frequency & Percent \\
\hline 1 & Nothing & 10 & 5.0 \\
\hline 2 & Very little & 30 & 15.0 \\
\hline 3 & A little & 31 & 15.5 \\
\hline 4 & On the average & 76 & 38.0 \\
\hline 5 & Most & 40 & 20.0 \\
\hline 6 & Everything & 13 & 6.5 \\
\hline & Total & 200 & 100.0 \\
\hline
\end{tabular}

Tab. 2 Respondents' opinion about awareness of management class in terms of organizational structure

Source: Authors' research.

Based on the data we can say so that there is little awareness of the Albanian managers' class on the importance of the structure.

To the Question no 24: How much do you know about business organizational strategy?

We have even a worse situation as the structures case. The answer "I have average knowledge "is given of the $27.5 \%$ respondents only. (See the table no 3).

\begin{tabular}{|l|l|l|l|}
\hline $\mathrm{Nr}$ & Alternatives & Frequency & Percent \\
\hline 1 & Nothing & 7 & 3.5 \\
\hline 2 & Very little & 38 & 19.0 \\
\hline 3 & A little & 49 & 24.5 \\
\hline 4 & On the average & 55 & 27.5 \\
\hline 5 & Most & 38 & 19.0 \\
\hline 6 & Everything & 13 & 6.5 \\
\hline & Total & 200 & 100.0 \\
\hline
\end{tabular}


Tab. 3 Respondents' opinion about awareness of management class in terms of organizational strategy Source: Authors' research.

\subsection{Analysis of Context Factors that guide the choice of the organizational structure at the Albanian business firms.}

Factor analysis estimates a priori the hypothesis, in analogy with the theory. The table, which shows the correlation matrix (comparing pairs of variables).It is used, as it is closely related to two important issues, first, variables can correlate with each other, but the values of these correlations are too low, caused them difficulty in determining the factor. So, in other words, depending on the coefficients correlation between pairs of variables, we could find out which of them has a significant value, serving as a factor in the analysis of factors.

The analyze by the Paired-Samples $t$ Test will help comparing the averages of the perception assesment about impact of factors listed by the interviewers responding to the question 19 of the questioner (Q_19_1,2,3,4,5,6,7,8): Question no 19 : Which context factors have had impact on the new or changed structure in your company?

Once we obtain the correlation matrix, (using SPPS 20 -software) we should define the method of the analysis; Factor Analysis or Principal Component Analysis. In our survey we used the method of Principal Component Analysis with assumptions, that total variance of variables to consider, depends on the variances of each component (factor) and the variance of the error is zero Thompson, (2004).

From the matrix of correlations (Table no. 4), it seems that no one of variables has a significant impact on others, so we should have to analyze the importance of each of the factors. For this, first we build striped graph averages and confidence intervals, $95 \%$ and see which of them is more important. 
Table no. 4 Correlations The Perception of The Contextual

Factors Impact on structure

\begin{tabular}{|c|c|c|c|c|c|c|c|c|c|}
\hline $\begin{array}{l}\text { The Perception } \\
\text { of The } \\
\text { Contextual } \\
\text { Factors Impact } \\
\text { on } \\
\text { Structure/Organization } \\
\text { al Design }\end{array}$ & & $\begin{array}{l}\text { Q_19_1 } \\
\text { Peroepti } \\
\text { on about } \\
\text { Strategy } \\
\text { impact }\end{array}$ & $\begin{array}{l}\text { Q_19_2 } \\
\text { Percept } \\
\text { on about } \\
\text { Technol } \\
\text { ogy } \\
\text { impact }\end{array}$ & $\mid \begin{array}{l}\text { Q_19_3 } \\
\text { Perception } \\
\text { about } \\
\text { Digitalizatio } \\
n \text { impact }\end{array}$ & $\begin{array}{l}\text { Q_19_4 } \\
\text { Perception } \\
\text { of the } \\
\text { business } \\
\text { environment } \\
\text { impact }\end{array}$ & $\begin{array}{l}\text { Q_19_ } \\
5 \\
\text { Percept } \\
\text { ion of } \\
\text { the } \\
\text { Globali } \\
\text { zation } \\
\text { impact }\end{array}$ & $\begin{array}{l}\text { Q_19_6 } \\
\text { Percept } \\
\text { on of the } \\
\text { Competit } \\
\text { ion } \\
\text { impact }\end{array}$ & $\begin{array}{l}\text { Q_19_7 } \\
\text { Perception of } \\
\text { the Business } \\
\text { Model impact }\end{array}$ & $\begin{array}{l}\text { Q_19_8 } \\
\text { Perceptio } \\
\text { n of the } \\
\text { consumer } \\
\text { s change } \\
\text { impact }\end{array}$ \\
\hline $\begin{array}{l}\text { Q_19_1 Perception of } \\
\text { the Strategy impact }\end{array}$ & $\begin{array}{l}\text { Pearson } \\
\text { Correlation } \\
\text { Sig. (2-tailed) } \\
\mathrm{N}\end{array}$ & 200 & .080 & $\begin{array}{l}-.255^{\circ} \\
.000 \\
200\end{array}$ & $\begin{array}{l}.342^{*} \\
.000 \\
200\end{array}$ & $\begin{array}{l}.163^{*} \\
.021 \\
200\end{array}$ & $\begin{array}{l}-.091 \\
.198 \\
200\end{array}$ & $\begin{array}{l}.215^{+} \\
.002 \\
200\end{array}$ & $\begin{array}{l}-.304^{*} \\
.000 \\
200\end{array}$ \\
\hline $\begin{array}{l}\text { Q_19_ Perception of } \\
\text { the Technology } \\
\text { impact }\end{array}$ & $\begin{array}{l}\text { Pearson } \\
\text { Correlation } \\
\text { Sig. (2-tailed) } \\
\text { N }\end{array}$ & 2080 & 200 & $\begin{array}{l}-.303^{+} \\
.000 \\
200\end{array}$ & $\begin{array}{l}.002 \\
.980 \\
200\end{array}$ & $.176^{*}$ & $\begin{array}{l}-.044 \\
.532 \\
200\end{array}$ & $\begin{array}{l}.575^{+} \\
.000 \\
200\end{array}$ & $\begin{array}{l}-.265^{\circ} \\
.000 \\
200\end{array}$ \\
\hline $\begin{array}{l}\text { Q_19_3 Perception of } \\
\text { the Digitalization } \\
\text { impact (Computer } \\
\text { linternet) }\end{array}$ & $\begin{array}{l}\text { Pearson } \\
\text { Correlafion } \\
\text { Sig. (2-tailed) } \\
\text { N }\end{array}$ & $\begin{array}{l}-.255^{+} \\
.000 \\
200\end{array}$ & $\begin{array}{l}-.303^{*} \\
.000 \\
200\end{array}$ & 200 & $\begin{array}{l}-.170^{*} \\
.016 \\
200\end{array}$ & $\begin{array}{l}-.061 \\
.393 \\
200\end{array}$ & $\begin{array}{l}-.061 \\
.392 \\
200\end{array}$ & $\begin{array}{l}-.284^{*} \\
.000 \\
200\end{array}$ & $\begin{array}{l}.114 \\
.108 \\
200\end{array}$ \\
\hline $\begin{array}{l}\text { Q_19_4 } \\
\text { Perception of the } \\
\text { ebusiness nvironment } \\
\text { impact }\end{array}$ & $\begin{array}{l}\text { Pearson } \\
\text { Correlation } \\
\text { Sig. (2-tailed) } \\
\text { N }\end{array}$ & 2000 & $\begin{array}{l}.002 \\
.980 \\
200\end{array}$ & $\begin{array}{l}-.170^{*} \\
.016 \\
200\end{array}$ & 200 & $\begin{array}{l}.145^{+} \\
.041 \\
200\end{array}$ & $\begin{array}{l}-.187^{*} \\
.008 \\
200\end{array}$ & $\begin{array}{l}.076 \\
.282 \\
200\end{array}$ & $\begin{array}{l}-.142^{*} \\
.045 \\
200\end{array}$ \\
\hline $\begin{array}{l}\text { Q_19_5 Perception of } \\
\text { the } \\
\text { impact }\end{array}$ & $\begin{array}{l}\text { Pearson } \\
\text { Correlation } \\
\text { Sig. (2-tailed) } \\
\text { N }\end{array}$ & $\begin{array}{l}163^{*} \\
.021 \\
200\end{array}$ & $\begin{array}{l}.176^{*} \\
.012 \\
200\end{array}$ & $\begin{array}{l}-.061 \\
.393 \\
200\end{array}$ & $\begin{array}{l}.145^{+} \\
.041 \\
200\end{array}$ & 200 & $\begin{array}{l}.047 \\
.508 \\
200\end{array}$ & $\begin{array}{l}.154^{*} \\
.030 \\
200\end{array}$ & $\begin{array}{l}-.122 \\
.084 \\
200\end{array}$ \\
\hline
\end{tabular}




\begin{tabular}{|c|c|c|c|c|c|c|c|c|c|}
\hline \multicolumn{2}{|c|}{$\begin{array}{l}\text { Q_19_6 Perception of Pearson } \\
\text { the } \\
\text { impact }\end{array}$} & $\begin{array}{l}-.091 \\
.198\end{array}$ & $\begin{array}{l}-.044 \\
.532\end{array}$ & $\begin{array}{l}-.061 \\
.392\end{array}$ & $\begin{array}{l}-.187^{\prime \prime} \\
.008\end{array}$ & .508 & 1 & .055 & $\begin{array}{l}-.254^{*} \\
.000\end{array}$ \\
\hline & $\mathrm{N}$ & 200 & 200 & 200 & 200 & 200 & 200 & 200 & 200 \\
\hline \multicolumn{2}{|c|}{$\begin{array}{l}\text { Q_19_7 Perception of Pearson } \\
\text { the Buziness Model Correlation } \\
\text { impact }\end{array}$} & $\begin{array}{l}215^{+*} \\
.002\end{array}$ & $\begin{array}{l}.575^{+} \\
.000\end{array}$ & $\begin{array}{l}-.284^{*} \\
.000\end{array}$ & $\begin{array}{l}.076 \\
.282\end{array}$ & $\begin{array}{l}.154^{*} \\
.030\end{array}$ & $\begin{array}{l}.136 \\
.055\end{array}$ & 1 & $\begin{array}{l}-.308^{*} \\
.000\end{array}$ \\
\hline & $\mathrm{N}$ & 200 & 200 & 200 & 200 & 200 & 200 & 200 & 200 \\
\hline \multirow[t]{2}{*}{$\begin{array}{l}\text { Q_19_8 Perception of } \\
\text { the consumer } \\
\text { consumers change } \\
\text { impact }\end{array}$} & $\begin{array}{l}\text { Pearson } \\
\text { Correlation } \\
\text { Sig. (2-tailed) }\end{array}$ & $\begin{array}{l}-.304^{*} \\
.000\end{array}$ & $\begin{array}{l}-.265^{+} \\
.000\end{array}$ & .114 & $\begin{array}{l}-.142^{*} \\
.045\end{array}$ & $\begin{array}{l}-.122 \\
.084\end{array}$ & $\begin{array}{l}-.254^{*} \\
.000\end{array}$ & $\begin{array}{l}-.308^{*} \\
.000\end{array}$ & 1 \\
\hline & $\mathrm{N}$ & 200 & 200 & 200 & 200 & 200 & 200 & 200 & 200 \\
\hline
\end{tabular}

**. Correlation is significant at the 0.01 level (2-tailed).

*. Correlation is significant at the 0.05 level (2-tailed).

Table no.5 Paired Samples Statistics- Competition/ Strategy impact

\begin{tabular}{|l|l|l|l|l|}
\hline & Mean & N & $\begin{array}{l}\text { Std. } \\
\text { Deviation }\end{array}$ & $\begin{array}{l}\text { Std. Error } \\
\text { Mean }\end{array}$ \\
\hline $\begin{array}{l}\text { Pair 1 Q_19_6 Perception } \\
\text { of the Competition } \\
\text { impact }\end{array}$ & 8.70 & 200 & 1.611 & .114 \\
$\begin{array}{l}\text { Q_19_1 Perception } \\
\text { of the Strategy } \\
\text { impact } 8.21\end{array}$ & 200 & 1.542 & .109 \\
\hline
\end{tabular}

Table no.5 /2 Paired Samples Correlations

\begin{tabular}{|ll|l|l|l|}
\hline & N & Correlation & Sig. \\
\hline Pair 1 & $\begin{array}{l}\text { Q_19_6 Perception of the } \\
\text { Competition impact \& Q_19_1 } \\
\text { Perception of the Strategy impact }\end{array}$ & 200 & -.091 & .198 \\
\hline
\end{tabular}


Table no.5 /3 Paired Samples Test

\begin{tabular}{|c|c|c|c|c|c|c|c|c|c|c|}
\hline & & \multicolumn{6}{|c|}{ Paired Differences } & \multirow[b]{3}{*}{$t$} & \multirow[b]{3}{*}{ df } & \multirow[b]{3}{*}{ Sig. (2-tailed) } \\
\hline & & \multirow[b]{2}{*}{ Mean } & \multirow[b]{2}{*}{ Std. Deviation } & \multirow{2}{*}{$\begin{array}{l}\text { Std. } \\
\text { Mean }\end{array}$} & \multirow{2}{*}{ Error } & \multicolumn{2}{|c|}{$\begin{array}{l}95 \% \text { Confidence Interval of } \\
\text { the Difference }\end{array}$} & & & \\
\hline & & & & & & Lower & Upper & & & \\
\hline Pair 1 & $\begin{array}{l}\text { Q_19_6 Perception of } \\
\text { the Competition impact } \\
\& \text { Q_19_1 Perception of } \\
\text { the Strategy impact }\end{array}$ & .485 & 2.330 & .165 & & .160 & .810 & 2.944 & 199 & .004 \\
\hline
\end{tabular}

Table no.6 /Paired Samples Statistics

\begin{tabular}{|c|c|c|c|c|}
\hline & Mean & N & Std. Deviation & Std. Error Mean \\
\hline $\begin{array}{l}\text { Pair } 1 \text { Q_19_1 Perception of the } \\
\text { Strategy Impact } \\
\text { Q_19_7 Perception of the } \\
\text { business Model Impact }\end{array}$ & $\begin{array}{l}8.21 \\
8.00\end{array}$ & $\begin{array}{l}200 \\
200\end{array}$ & $\begin{array}{l}1.542 \\
1.888\end{array}$ & $\begin{array}{l}.109 \\
.133\end{array}$ \\
\hline
\end{tabular}

Table no.6 /2Paired Samples Correlations

\begin{tabular}{|l|l|l|l|}
\hline & $N$ & $\begin{array}{l}\text { Correlatio } \\
n\end{array}$ & Sig. \\
\hline $\begin{array}{l}\text { Pair 1 Q_19_1 Perception } \\
\text { of the Strategy }\end{array}$ & & & \\
$\begin{array}{l}\text { Impact \& } \\
\text { Q_19_7 Perception } \\
\text { of the business } \\
\text { Model Impact }\end{array}$ & & .215 & .002 \\
\hline
\end{tabular}

Table no.6 /3Paired Samples Test

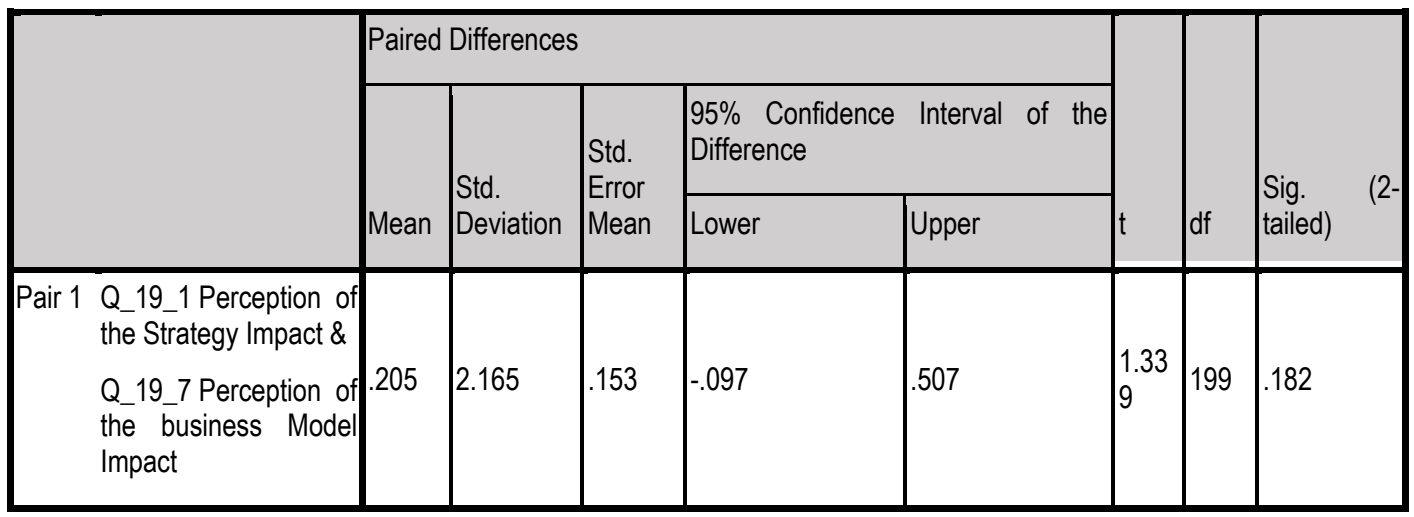


It seems from the chart below (Figure no.2)that the perception on the impact of the variables that significantly affect more than others the structure are; Competition (Q_19_6), then the Business Model(Q_19_7),Strategy (Q_19_1), and Technology(Q_19_2).That means it is requiring a more detailed analysis of them.

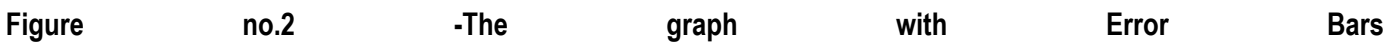

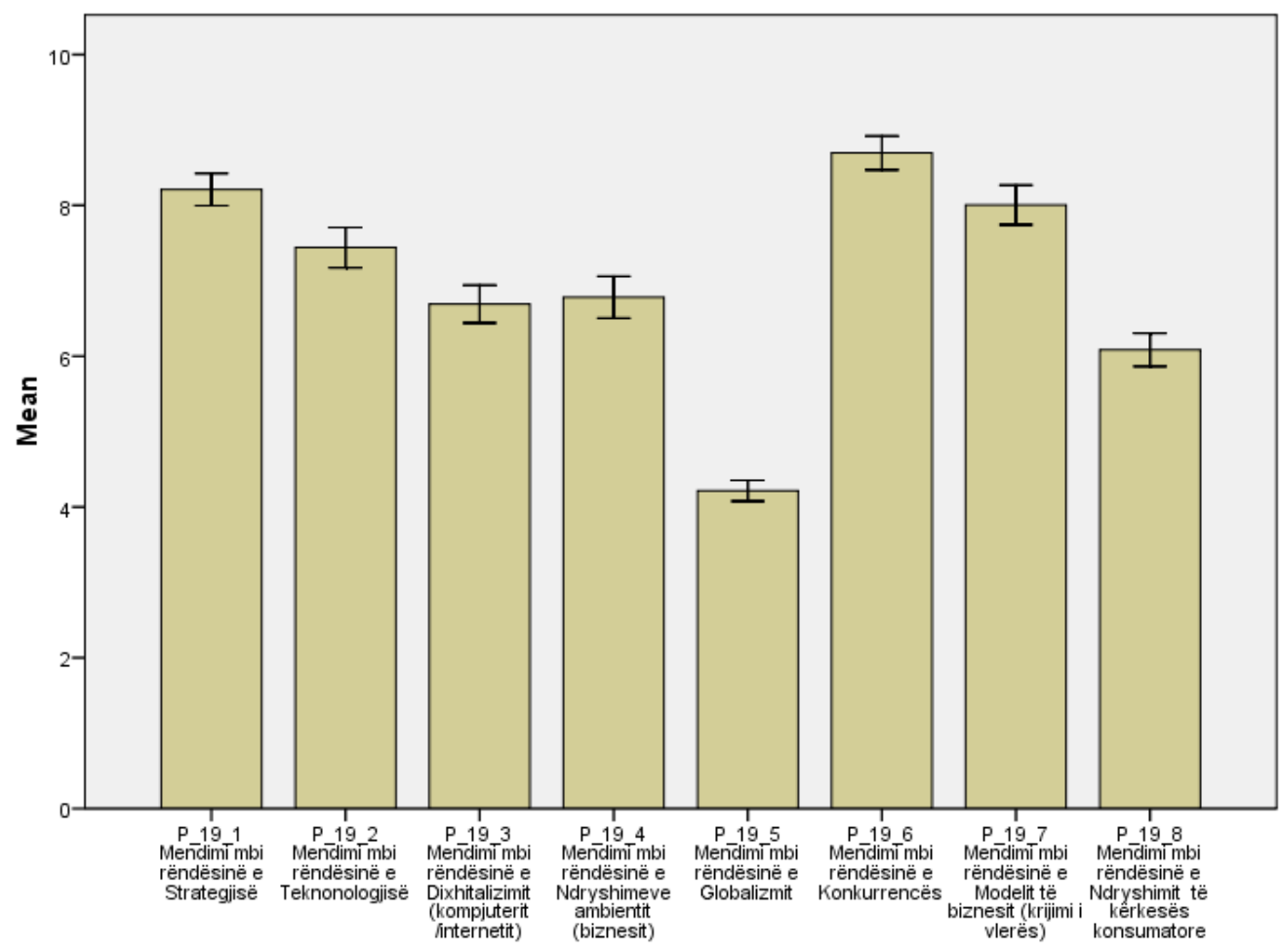

Error Bars: $95 \% \mathrm{Cl}$

For this we do compare their averages by paired Samples t-Test. By comparing the averages of the perception assesment about impact of the Strategy (Q_19_1 )and the Competition (Q_19_6) on structure we note from the first table; that the averages are respectively 8.70 and 8.21 and standard deviation respectively 1.611 and 1.542 with the standard error average respectively 0.114 and 0109 ( Table no.5).

From the second table, we note that they have a correlation of 0.198 and the significance 0.09 which means they are not related (correlated) ( Table no.5/2).

In the third table, we note that the Average / Mean $=0485, t=2,944$ and $p=0.004<0.005$. The mutual Probability of Competition assessment (Q_19_6) is very low $(p=.027)$ and in fact shows us that there is only a $0.4 \%$ chance that the value " $t$ "can be great if the null hypothesis is true, therefore, this " $t$ " is important because it is less than .05. ) ( Table no.5/3 ).

The fact that the value $t$ is a positive number indicates that the first context factor (perception on the impact of the Competition (Q_19_6) has the average more than the second one (perception on the impact of the Strategy (Q_19_1) and so this context factor -the Competition (Q_19_6),convinces us for an assessment higher than the other one the Strategy (Q_19_1). Therefore, we can conclude that the question of the importance of the Competition (Q_19_6) provides an estimate with a greater significance than that of the importance of the Strategy (Q_19_1), $t=2,944$ and $p=0.004<0.005$. This result was predicted by the graph with error bars. (Fig.no.1). 
By the Paired-Samples $t$ Test comparing the averages of the perception assesment about impact of the Strategy (Q_19_1 )and the Business Model (Q_19_7) on structure we note from the first table that the averages are respectively 8.21 and 8.00 and standard deviation respectively 1.542 and 1.888 and the average standard error respectively 0.109 and 0.133 . ) (Table no.6).

From the second table, (Table no.6/2).we note that they have correlation 0.215 and significance 0.002 which means they are not related (correlated).

In the third table, (Table no.6 /3, we note that the Average / Mean $=0.205, t=1.339$ and $p=0.182>0.005$.

Mutual probability of Strategy assessment $\left(Q_{-} 19 \_1\right)$ was high $(p=.182)$ and in fact it shows us that there is only a $18.2 \%$ chance that the value " $\mathrm{t}$ " can be great if the null hypothesis is true, therefore, this " $\mathrm{t}$ "is not important because it is greater than .05 .

The fact that the value " $\mathrm{t}$ "is a positive number indicates that the first factor Strategy (the perception of the importance of the Strategy Q_19_1) is greater than the average of second- factor technology (perception of the Business Model (Q_19_7) however, the first factor strategy (Q_19_1) not convince us to a higher rating than the Business Model (Q_19_7).

Therefore, we can conclude that both questions about the importance of the Strategy (Q_19_1) and the Business Model (Q_19_7) provide us an assessment of the same significance, $t=1.339$ and $p=0182>0.005$.

This result was predicted by the graph with error bars.(fig.no.1)

By the Paired-Samples $t$ Test comparing the averages of the perception assesment about impact of the Strategy (Q_19_1 )and the Technology (Q_19_2) on structure we note from the first table (Table no.7) that the averages are respectively 8.21 and 7.44 and standard deviation respectively 1.542 and 1.906 and the standard error Mean respectively 0.109 and 0.135 .

From the second table, we note that they have correlation 0.080 and significance 0.263 which means they are not related (correlated) (Table no.7/2).

In the third table, (Table no.7/3) we note that the Average / Mean $=0.770, t=4.624$ and $p=0.0>0.005$.

Mutual probability of Strategy assessment (Q_19_1) was high $(p=.0)$ and in fact it shows us that there is only a $0 \%$ chance that the value " $\mathrm{t}$ " can be great if the null hypothesis is true, therefore, this " $\mathrm{t}$ "is not important because it is greater than .05 .

The fact that the value " $t$ "is a positive number indicates that the first factor Strategy (the perception of the importance of the Strategy Q_19_1) is greater than the average of second- factor technology (perception of the technology impact Q_19_2), however, the first factor strategy (Q_19_1) not convince us to a higher rating than technology one (Q_19_2.)

Therefore, we can conclude that both questions about the importance of the Strategy (Q_19_1) and Technology (Q_19_2) provide us an assessment of the same significance, $t=1.339$ and $p=0.0>0.005$. This result was predicted by the graph with error bars.(fig.no.1)

\section{Table no7.Paired Samples Statistics}

\begin{tabular}{|ll|l|l|l|l|}
\hline & & Mean & N & Std. Deviation & Std. Error Mean \\
\hline Pair 1 & $\begin{array}{l}\text { Q_19_1 Perception of the } \\
\text { Strategy Impact \& } \\
\begin{array}{l}\text { Q_19_2 Perception of the } \\
\text { Teknonology Impact }\end{array}\end{array}$ 7.44 & 200 & 1.542 & .109 \\
\hline
\end{tabular}

Table no7/2.Paired Samples Correlations 
organizational design. This lead us in the conclusion that the new trends as well as the challenges facing businesses in Albanian context, are the critical and guide their process of organizational design.

From the study conducted, we found that despite changes which have occurred in recent years in Albania, and in particular in Vlora, Fier, Lushnje, Saranda, Durres and Tirana, we still do have little managers' awareness about the importance of the organizational structure, strategy and design.

\section{Recommendations for Researchers}

Of interest would be the research about the structural dimensions that would be more present in organizations with high or low performance, or for organizations in certain sectors of the economy. So we could better understand their impact on organizational performance in the future.

In conclusion, the research reported in this paper has modestly provided few answers, but has generated some new research questions which seem to require further study. He has thrown little light on the controversy over the existence of fundamental universal dimensions of organizational structure, but he has suggested an approach that could be helpful in determining the existence or non-existence of these dimensions. Moreover, he has raised an opportunity for researchers about some relatively successful organizations structures which could be described differently and independently by several dimensions.

\section{REFERENCES}

Aquinas PG, Organization Structure \& Design : Applications And Challenge, Excel Books India 2009

Burlton R. T., (2001) Business Process Management: Profiting From Process Sams Publishing,

Burns T., Stalker G. M., (1961, 1994), The Management of Innovation, London: Tavistock, Oxford University Press,

Burton, R.. M.., Organization Design: The Evolving State-of-the-Art ,Springer, 2006

Burton R. M., Eriksen B., Håkonsson D., \& Snow Ch. C. (2006), Organization Design: The Evolving State-of-the-Art. New York: Springer.

Burton R. M., Obel B., (2004), Strategic Organizational Diagnosis and Design: The dynamic of fit. New York: Springer.

Burton, R., M. Obel B., (2004)Strategic Organizational Diagnosis And Design The Dynamics Of Fit Third Edition Springer Science+Business Media, Llc

Burton, R., M. Obel B.,and Gerardine De Sanctis (2011)Organizational Design: A Step-by-Step Approach,Cambridge University Press

Child J(1997),( 2013), Strategic Choice in the Analysis of Action, Structure, Organizations and Environment: Retrospect and Prospect, SAGE at Stockholm University, DOI: 10.1177/017084069701800104,Organization Studies 1997 18: 43

Cunliffe A. L ., \& Luhman, T., (2012), Key Concepts in Organization Theory. SAGE Publications Ltd.

Daft R. L., \& Armstrong A. (2012), Organization Theory and Design, Canada: Nelson Education Ltd.

Davenport Harris \& Morison (2010).Analytics at Work: Smarter Decisions, Better Results, Harvard Business Review Press, 2010

Davenport Thomas H. and Harris Jeanne G. $(, 2007,2013)$ Competing on Analytics: The New Science of Winning, Harvard Business Review Press

David A. Nadler, Robert B. Shaw , A. Elise Walton, (1994) Discontinuous Change: Leading Organizational Transformation. Jossey-Bass

Di Jay R. Galbraith,Diane Downey,Amy Kates (2009), Designing Dynamic Organizations: A Hands-on Guide for Leaders at All Levels .New approaches to organization design. Springer.

Donaldson, L. (2013). Organizational structure and design. In E. Kessler (Ed.), Encyclopedia of management theory. (pp. 570-575). Thousand Oaks, CA: SAGE Publications, Inc

Donaldson, Lex. (2014)"Encyclopedia of Management Theory." Thousand Oaks, CA: SAGE Publications, Inc.

Dans, E., (2015), The age of holacracy.Organisations of the future will function with no job titles, managers or hierarchies, The Times group e-paper.

Field, A. (2005). Discovering statistics using SPSS. (Introducing Statistical Methods series) London: Sage Publications Ltd Hernaus, T.,(2008), Generic Process Transformati Model:Transition To Process-Based Organization EFZG Working Papers Series 0807 FEB, University of Zagreb.

Hinkin T.R., (1995), 'A review of scale development practices in the study

Huber G.P. (2009). New Approaches to Organization Design. : Springer, 2009

Huber G.P. (2009). Use of the theory on organizational design. USA Springer 
Implications of the fit between organizational structure and ERP: A structural contingency theory perspective. International Journal of Information Management, 28(5), 391-402

Improvisation and Innovative Performance in Teams Organization Science (2005) 16:203-224

in transition?', Problems of Economic Transition, vol 43, no 12, 6-49.

Inside the workplace:Findings from 2004 Workplace Employment Relations Survey, London: Routledge.

Jay Galbraith Diane ,Downey Amy \&Kates (2001),Designing Dynamic Organizations: A Hands-on Guide for Leaders at All Levels.

Jelinek, S., The Impact of Management Practices and Organizational Structure on Firm Performance: A Cross Country Empirical Analysis GRIN Verlag, 2010

John Child, (Jun., 1973), pp. 168-185 Predicting and Understanding Organization Structure Administrative Science QuarterlyVol. 18, No. 2

Kates A. Galbraith J.R., (2010),Designing Your Organization;Using the STAR Model to Solve 5 Critical Design Challenges, John Wiley \& Sons

Kates, A. Galbraith, J. R. ,(2007) Designing your organization: using the star model to solve 5 critical design challenges. John Wiley \& Sons, Inc

Kersley B.,Alpin C.,Forth J.,BrysonA.,Bewley H., (Dix ,G.,Oxenbridge ,S.2006),

Khandwalla P., (1976), The Design of Organizations. New York:Harcourt

Kimberly WYLIE, Organizational Structure Metaphors, GRIN Verlag, 2006

Kirk Dean Fiedler, Varun Grover and James T. C. Teng,Journal of Management Information Systems Vol. 13, No. 1 (Summer, 1996), pp. 9-34

Lægaard J. \& Bindslev M., (2006) Organizational Theory, Ventus Publishing Aps

Lægaard, J. Bindslev , M. Organizational theory, Ventus Publishing ApS, 2006

Laloux F., (2014), Reinventing Organizations: A Guide to Creating Organizations Inspired by the Next Stage in Human Consciousness, Nelson Parker,

Lawler E. III E dhe Worley. Ch .G., (2011),Built to Change: How to Achieve Sustained Organizational Effectiveness .John Wiley \& Sons.

Lawler III E.E.,(1996) From the ground six Principles for Building the new Logic Corporation, Joseey -Bass.S.Francisco

Lawler III, E. E., (1996), Designing High Performance Organizations. San Francisco: Jossey-Bass.

Lawler III, E. E., (1996). From the ground up: Six principles for creating the new logic corporation. San Francisco: JosseyBass.

Leybourn , E., (2013) Directing the Agile Organization: A Lean Approach to Business Management It Governance publishing UK Prentice Hall

Liuhto K., (2001), 'How much does size, age, or industry membership matter, Organization Science

Llaci Sh., (2006), Manaxhimi, Tiranë.

Lowell L. Bryan, Claudia L. Joyce, (2007) Mobilizing Minds: Creating Wealth From Talent in the 21st Century Organization Mc Graw- Hill

Maria Guadalupe,Julie Wulf,The Flattening Firm And Product Market Competition:The Effect Of Trade Liberalization, NBER Ëorking Paper No. 14491,November 2008

Maung Kyaw Sein(2001),Contemporary Trends in Systems Development, Springer,

Mintzberg, H., (2011), Managing,Berrett-Koehler Publishers,

Mintzberg, H.,,( 1983,1992),Structure in 5's: Designing Effective Organizations,Prentice Hall,.

Mintzberg, H.,,(1979), The Structuring of Organizations: A Synthesis of the Research,Prentice-Hall,

Nielsen, C. \& Lund, M. (2013), An introduction to business models, in Nielsen, C. (Ed.) The Basics of Business Models, Vol. 1, No. 1. Copenhagen: Ventus Publishing Aps

of organizations', Journal of Management, vol 21, no 5, 967-988.

P.G Aquinas , (2009),Organization Structure and Design : Applications \& Challenges. Excel Books India Organization Science September/October 1998 vol. 9 no. 5 556-568

Pugh, D., S. Hickson D., J. (2007), Great Writers on Organizations,ASHGATE

Hall R., H. (1991) Organizations: Structures, Processes and Results Prentice Hall

Richard S. Blackburn (1982), Dimensions of Structure: A Review and Reappraisal ;The Academy of Management Review Vol. 7, No. 1 fq. 59-66

Robbins, Stephen P., (2009) Organization Theory: Structure, Design, And Applications, 3/E Pearson Education. 
Robbins, Stephen P.,( 1990).Organization Theory: Structure, Design and Applications, Prentice Hall International Editions, New Jersey.

Robin Smith, (2000)Chemical Process: Design and Integration, John Wiley \& Sons, Inc.

Uzzi, B. (1996) "The Sources and Consequences of Embeddedness for the Economic Performance of Organizations." American Sociological Review 61:674-98

Vuksiç B, V.,Hernaus T.,\& Kovaçiç A., (2008).Upralvanje poslovnim Procesima:Organizacijski I informacijskipristup.Zagreb Skolska knjiga

Walsh J. P. , Meyer A. D., Schoonhoven C .B.( 2006) A Future for Organization Theory: Living in and Living with Changing Organizations Organization Science Vol. 17, No. 5, , fq. 657-671

Welsh (III.)W.O.(2007)Transformation Changes Everything: Exploring Organizational Leadership Challenges in an "aspiring-to" Transformative Environment,ProQuest

Worren N., (2011) Hitting the Sweet Spot Between Separation and Integration in Organization Design, People and Strategy. Academia Edu.

Wrzesniewski, A., \& Dutton, J. E. (2001). Crafting a job: Revisioning employees as active crafters of their work. Academy of Management Review, 26(2), 179-201.

Wulf J, Working (2012),Paper Harvard business Review 12-087

Zachry, M. \& Thralls C., (2007), Communicative practices in workplaces and the professions: Cultural perspectives on the regulation of discourse and organizations. Amityville, NY: Baywood Publishing.

\section{ANEXES}

Paired Samples Statistics Techonology / Business Environment Change Impact

\begin{tabular}{|ll|l|l|l|l|}
\hline & Mean & N & Std. Deviation & Std. Error Mean \\
\hline Pair 1 & $\begin{array}{l}\text { Q_19_2 Perception of the } \\
\text { Techonology impact } \\
\begin{array}{l}\text { Q_19_4 Perception of the business } \\
\text { environment change impact }\end{array}\end{array} 6.78$ & 200 & 1.993 & .135 \\
\hline
\end{tabular}

\section{Paired Samples Correlations}

\begin{tabular}{|ll|l|l|l|}
\hline & Correlation & Sig. \\
\hline Pair1 & $\begin{array}{l}\text { Q_19_2 Perception of the } \\
\text { Techonology impact \& Q_19_4 } \\
\text { Perception of the business } \\
\text { environment change impact }\end{array}$ & 200 & .002 & .980 \\
\hline
\end{tabular}




\section{Paired Samples Test}

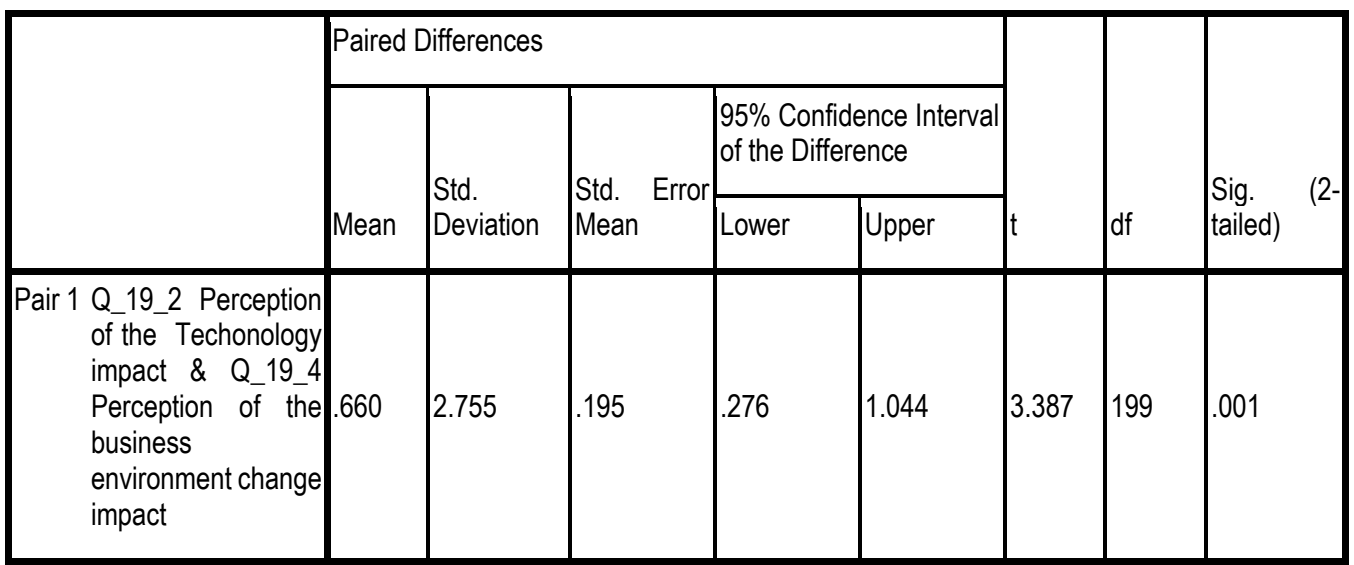

Paired Samples Statistics Digitalization /Business Environment Change Impact

\begin{tabular}{|ll|l|l|l|l|}
\hline & Mean & N & Std. Deviation & Std. Error Mean \\
\hline Pair 1 $\begin{array}{l}\text { Q_19_3 Perception of the Digitalization } \\
\text { impact (Computer /internet) }\end{array}$ & 6.69 & 200 & 1.789 & .126 \\
$\begin{array}{l}\text { Q_19_4 Perception of the business } \\
\text { environment change impact }\end{array}$ & 6.78 & 200 & 1.993 & .141 \\
\hline
\end{tabular}

Paired Samples Correlations

\begin{tabular}{|c|c|c|c|c|}
\hline & & $\mathrm{N}$ & Correlation & Sig. \\
\hline Pair 1 & $\begin{array}{l}\text { Q_19_3 Perception of the Digitalization } \\
\text { impact } \\
\text { Q_19_4 Perception of the business } \\
\text { environment change impact }\end{array}$ & 200 & -.170 & .016 \\
\hline
\end{tabular}




\section{Paired Samples Test}

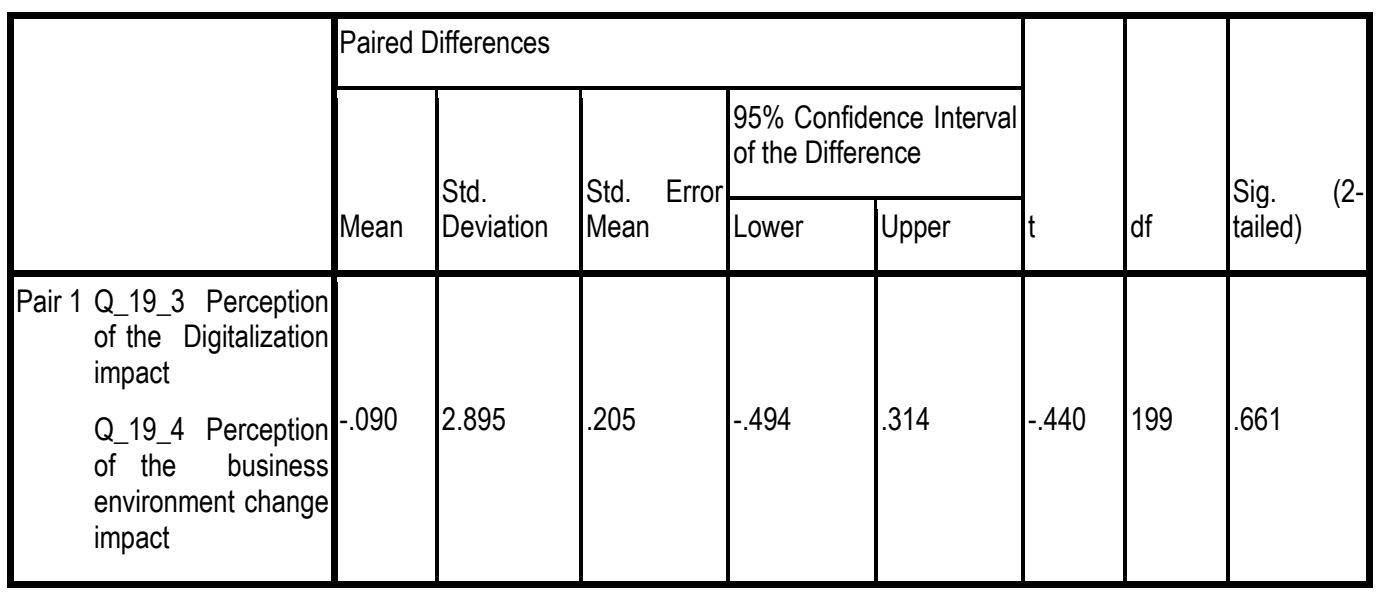

Paired Samples Statistics Business environment change/ Consumer Request Change Impact

\begin{tabular}{|c|c|c|c|c|c|c|}
\hline & & & Mean & $\mathrm{N}$ & Std. Deviation & Std. Error Mean \\
\hline Pair 1 & $\begin{array}{l}\text { Q_19_4 } \\
\text { business } \\
\text { impact } \\
\text { Q_19_8 } \\
\text { Consumer } \\
\text { Impact }\end{array}$ & $\begin{array}{l}\text { Perception of the } \\
\text { environment change } \\
\text { Perception of the } \\
\text { Request Change }\end{array}$ & $\begin{array}{l}6.78 \\
6.08\end{array}$ & 200 & 1.993 & .141 \\
\hline
\end{tabular}

Paired Samples Correlations

\begin{tabular}{|c|c|c|c|c|}
\hline & & $N$ & $\begin{array}{l}\text { Correlati } \\
\text { on }\end{array}$ & Sig. \\
\hline $\begin{array}{l}\text { Pair } \\
1\end{array}$ & $\begin{array}{l}\text { Q_19_4 } \\
\text { Perception of the } \\
\text { business } \\
\text { environment } \\
\text { change impact } \\
\text { Q_19_8 } \\
\text { Perception of the } \\
\text { Consumer } \\
\text { Request Change } \\
\text { Impact }\end{array}$ & 200 & -.142 & .045 \\
\hline
\end{tabular}

Paired Samples Test 


\section{Paired Samples Correlations}

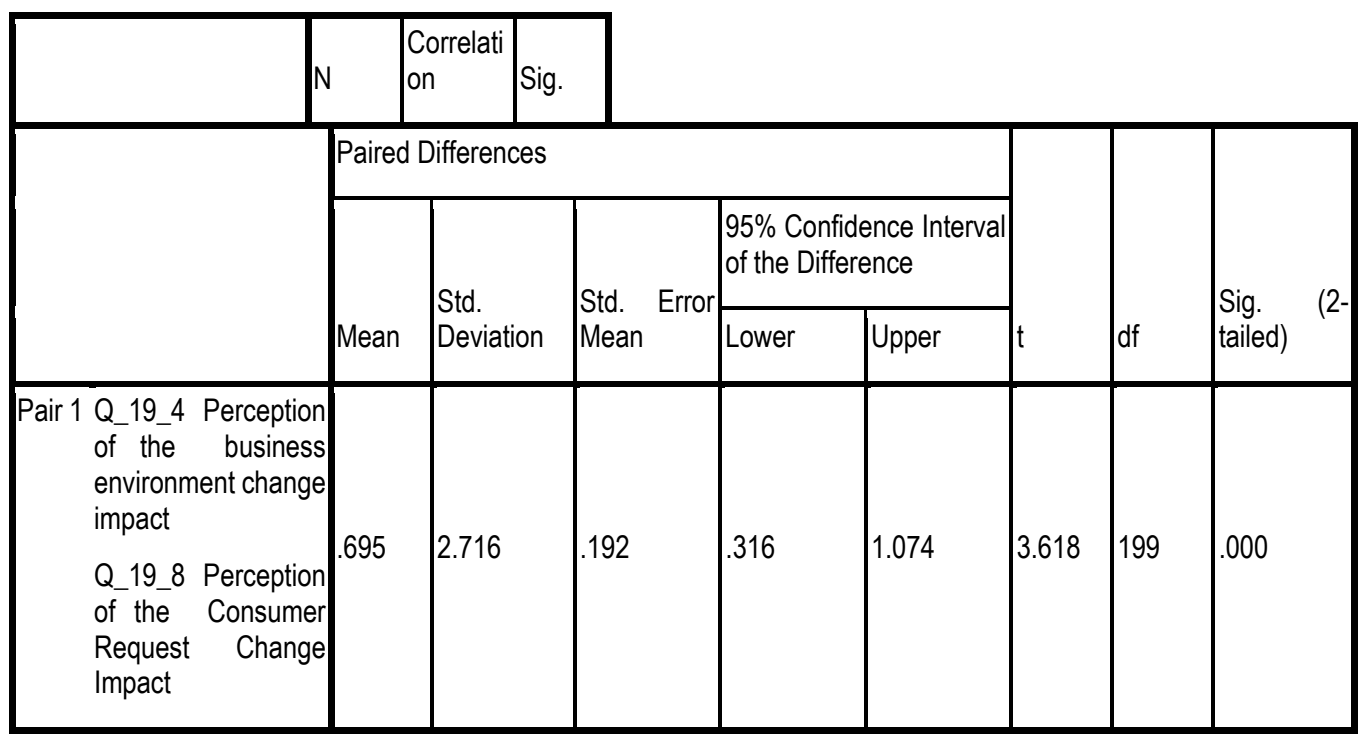

